\title{
A case of granulomatous hypophysitis with hypopituitarism and minimal pituitary enlargement
}

\author{
PATRICE HASSOUN, ELYAS ANAYSSI, IBRAHIM SALTI \\ From the Departments of Pathology and Internal Medicine, Faculty of Medicine, American University of \\ Beirut, Beirut, Lebanon
}

SUMMARY A case of hypopituitarism and minimal sellar enlargement was found at hypophysectomy to have a giant cell granuloma of the pituitary. The clinical and histopathological features of this rare entity are reviewed. It is proposed that hypopituitarism which is out of proportion to minimal sellar enlargement may be a suggestive clue to the preoperative diagnosis of giant cell granulous which normally simulates a pituitary tumour.

Granulomatous diseases of the pituitary are uncommon disorders which are rarely diagnosed in patients presenting for hypophysectomy. ${ }^{1-4}$ The majority of reported cases come from neuropsy material ${ }^{5-7}$ and include infectious and systemic diseases such as tuberculosis, ${ }^{2-8}$ sarcoidosis, ${ }^{1-6}$ syphilis and fungal infections. However, when such specific aetiologies are excluded, there remains a small group of patients in whom the granulomatous disorder is of unknown origin and in whom there is no systemic involvement with the granuloma apparently restricted to the pituitary gland. ${ }^{3-s}$

In this report we describe a patient who presented with hypopituitarism together with radiological findings of a small intrasellar tumour. The patient was subjected to a trans-sphenoidal hypophysectomy and proved to have a pituitary giant cell granuloma.

\section{Case report}

A 65-year-old woman presented with a two months history of anorexia, nausea, vomiting and weight loss of about 10 $\mathrm{kg}$. She had no headaches, visual complaints or abdominal symptoms. Physical examination revealed a sick elderly woman with a dry skin and slowing of speech and mentation. The visual fields, fundoscopic and neurological examinations were normal. The blood pressure was 90/70

Address for reprint requests: Dr I Salti, American University Medical Center, Beirut, Lebanon.

Received 4 May 1984 and in revised form 26 November 1984. Accepted 26 January 1985. $\mathrm{mm} \mathrm{Hg}$ and heart rate $76 /$ minute. The following tests gave normal results: fasting serum glucose, urea nitrogen, creatinine, albumin, globulin, cholesterol, calcium, phosphate, sodium, potassium and chloride. Urine analysis was normal with a specific gravity of 1028 . Haemoglobin was $11 \mathrm{~g} / \mathrm{dl}$ and haematocrit $34 \%$. The leukocyte count, leukocyte differential count and platelet count were normal. The erythrocyte sedimentation rate was $50 \mathrm{~mm} /$ hour. Serum VDRL was nonreactive.

In view of the persistent nausea and vomiting, computed tomography was performed and revealed rarefaction of the dorsum sellae and the lamina dura of the sella turcica. There was a double floor of the sella but the total sellar volume was not increased. There were no abnormalities in the suprasellar region.

Baseline endocrine tests were performed and are summarised in the table. Intravenous administration of $200 \mu \mathrm{g}$ of thyrotropin releasing hormone (TRH), resulted in no rise in serum prolactin or thyroid stimulating hormone. In view of the clinical state of the patient, an insulin-induced hypoglycaemia test was not done. Serum was negative for antithyroglobulin, antimicrosomal, anti-islet cell and antilactotrope antibodies. An intradermal tuberculin.test and chest radiography were negative. Serum was also negative for Brucella antibodies.

Treatment with intravenous hydrocortisone resulted in prompt clinical improvement and disappearance of the vomiting. A transphenoidal hypophysectomy was well tolerated by the patient. Thereafter, the patient was placed on maintenance doses of l-thyroxin and hydrocortisone. On regular bimonthly follow-up for the subsequent two years she was asymptomatic.

\section{Histopathology}

The excised pituitary tissue weighed $1.8 \mathrm{~g}$ and was firm in 
Table Base line hormonal tests

\begin{tabular}{lcc}
\hline Test & Result & Normal range \\
\hline Serum thyroxine & $3 \cdot 8$ & $4 \cdot 5-12 \cdot 0 \mu \mathrm{g} / \mathrm{dl}$ \\
Serum prolactin & $4 \cdot 1$ & $\begin{array}{c}5-20 \mathrm{ng} / \mathrm{ml} \\
50-200 \mathrm{mIU} / \mathrm{ml}\end{array}$ \\
$\begin{array}{l}\text { Serum follicle } \\
\quad \text { stimulating hormone }\end{array}$ & 15.8 & \\
$\begin{array}{l}\text { Serum luteinising hormone } \\
\text { Serum cortisol (8 am) }\end{array}$ & $9 \cdot 4$ & $50-200 \mathrm{mIU} / \mathrm{ml}^{*}$ \\
Serum thyroid stimulating & $1 \cdot 5$ & $6-26 \mu \mathrm{g} / \mathrm{dl}$ \\
$\quad$ hormone & 0.5 & $0.5-7 \mu \mathrm{U} / \mathrm{ml}$ \\
\hline
\end{tabular}

*Normal range for post-menopausal women.

consistency. Microscopic examination revealed almost total disruption of the normal architecture of the adenohypophysis, with a marked increase of fibroconnective stroma.

The most striking feature was the presence of large multinucleated giant cells surrounded by lymphocytes and plasma cells (fig). The pattern of the giant cell infiltrate was diffuse and not follicular as in sarcoidosis, tuberculosis or syphylis. A silver stain showed a haphazard reticular pattern in contrast to the nodular pattern that is usually seen in sarcoidosis. All special stains for acid fast bacilli, fungi and spirochetes were negative.

\section{Discussion}

The differential diagnosis of granulomatous hypophysitis whether discovered after hypophysectomy or at necropsy includes a number of granulomatous disorders such as tuberculosis, ${ }^{28}$ sarcoidosis, ${ }^{16}$ fungal infections or syphilis. ${ }^{7}$ In the absence of histological or systemic evidence of these diseases there remains a small group of patients in whom the granulomatous disease is of undetermined pathogenesis. ${ }^{3-5}$

The presenting problem in this patient was severe anterior pituitary failure as evidenced by subnormal levels of serum cortisol, thyroxin, prolactin and gonadotropins, and the failure of serum thyroid stimulating hormone and prolactin to rise after TRH administration. The combination of hypopituitarism

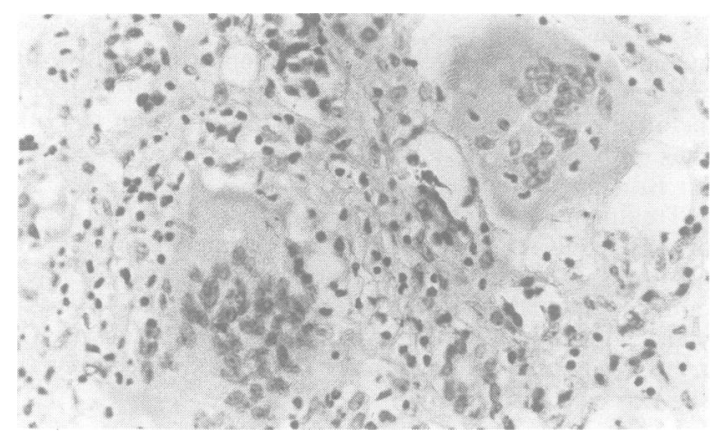

Figure Section of pituitary gland showing giant cells surrounded by lymphocytes and plasma cells $(H \& E$ $\times 200$ ). with the sellar abnormalities that were observed on CT scanning, was suggestive of a pituitary tumour. A review of the previously reported cases of giant cell granuloma of the pituitary revealed a similar presentation simulating a pituitary tumour with hypopituitarism and radiological evidence of minimal sellar enlargement. ${ }^{3-7}$ However, a common feature amongst these patients (including the present case) is that unlike pituitary neoplasms, the degree of pituitary failure is out of proportion to the minimal degree of sellar enlargement. A pituitary tumour producing little or no sellar enlargement is not expected to cause hypopituitarism unless it has major supra sellar extension.

Another feature of giant cell granuloma is that the course of the disease is more rapid than in the usual case of pituitary tumour ( $\mathrm{refs}^{3-5}$ and present case).

The pathogenesis of pituitary giant cell granuloma remains unknown. Although its clinical presentation bears many similarities to the recently described entity of autoimmune lymphocytic hypophysitis," 10 the two disorders are histologically distinguishable. Moreover, in lymphocytic hypophysitis which occurs mostly in postpartum women, there is an association with other autoimmune endocrine and non endocrine disorders ${ }^{1112}$ and the patients' sera are sometimes positive for antibodies against pituitar cells or other endocrine cells or antigens." These 0 antibodies were not detected in the serum of ou $\mathbb{8}$ patients.

Despite the obvious histological and immunologi cal differences between granulomatous and lym phocytic hypophysitis, a recent study by MckeeP suggest that there are common ultrastructural features between the two entities. ${ }^{13}$ The author suggests that the two disorders may simply be different stages of a single disease. This proposition needs further study.

The authors are grateful to Dr G Bottazzo, Middlesex Hospital for the assays of antilactotrope and other antibodies.

\section{References}

${ }^{\prime}$ Decker RE, Mardayat M, Marc J, Rasool A. Neurosarcoidosis with computerized tomographic visualization and transsphenoidal excision of a supra-and intrasellar granuloma. Case report. J Neurosurg 1979;50:814-6.

${ }^{2}$ Colman CC, Richmond VA, Meredith JM. Diffuse tuberculosis of the pituitary gland simulating tumour, with postoperative recovery. Arch Neurol 1940;44:1076.

${ }^{3}$ Taylor C, Duff TA. Giant cell granuloma involving the pituitary gland. Case report. J Neurosurg 1980; 52:584-7. 
${ }^{4}$ Delpozo JM, Roda JE, Montoya JG, Inglesias JR, Hurtado A. Intra sellar granuloma. J Neurosurg 1980;53:717-9.

${ }^{5}$ Doniach I, Wright EA. Two cases of giant cell granuloma of the pituitary. J Pathol Bacteriol 1951;63:69-79.

- Bleisch VR, Robbins SL. Sarcoid-like granulomata of the pituitary gland. Arch Int Med 1952;89:877-92.

7 Sheehan HL, Summers VK. The syndrome of hypopituitarism. $Q J$ Med 1949;18:319-78.

${ }^{8}$ Brooks MH, Dumlas JS, Bronsky D, Waldstein SS. Hypophysial tuberculoma with hypopituitarism. Am J Med 1977;54:777-80.

` Asa SL, Bilbao JM, Kovacs K, Josse RG, Kneines K.
Lymphocytic hypophysitis of pregnancy resulting in hypopituitarism: A distinct clinicopathologic entity. Ann Int Med 1981;95:166-71.

10 Topliss D, Volpe R. Lymphocytic hypophysitis. Ann Int Med 1981;95:227-8.

" Bottazo GF, Doniach D. Pituitary autoimmunity: A review. J $R$ Soc Med 1978;71:433-6.

12 Salti IS, Mouradian A, Amiri Z, Khalil A. Hypopituitarism in a patient with idiopathic hypoparathyroidism. Can Med Ass J 1982;126:942-3.

${ }^{13}$ Mckeel DW. Common histopathologic and ultrastructural features in granulomatous and lymphoid adenohypophysitis. Program of the 65 th annual meeting of the Endocrine Society 1983; Abstract 437. 